\title{
Starting of induction motor fed with stand-alone DFIG
}

\author{
M. Sharawy ${ }^{1}$, Adel A. Shaltout ${ }^{2}$, Naser Abdel-Rahim ${ }^{3}$, Mahmoud A. Al-Ahmar ${ }^{4}$, O. E. M. Youssef \\ ${ }^{1,4,5}$ Electrical Engineering Department, Faculty of Engineering at Shoubra, Benha University, Egypt \\ ${ }^{2}$ Electrical Power and Machines Department, Faculty of Engineering, Cairo University, Egypt \\ ${ }^{3}$ Electrical Engineering Department, Faculty of Engineering and Technology, Future University, Egypt
}

\begin{tabular}{l} 
Article Info \\
\hline Article history: \\
Received Jun 19, 2020 \\
Revised Feb 20, 2021 \\
Accepted Jul 27, 2021 \\
\hline Keywords: \\
3-phase induction motor \\
Constant V/f control \\
Indirect FOC \\
Stand-alone DFIG \\
WECS
\end{tabular}

\begin{abstract}
This paper presents dynamic simulation and control of stand-alone doubly fed induction generator (DFIG) loaded with 3-phase induction motors (IMs). The study reveals that direct on-line starting of large IMs causes a large voltage sag across the generator terminals as the starting current drawn reaches up to 8-9 times the rated load current. Traditionally, this problem has tackled by oversizing of the generator or employment of special starters, under the pretext of mitigating voltage sag. This work explores ways that the starting current can be reduced economically by applying constant V/f control side by side with indirect field-oriented control (FOC) applied on the rotor side converter of the DFIG. This methodology enables starting of larger IMs and mitigation of voltage sag that occurs during the start-up period. Two different rating of IMs loaded with speed-squared mechanical torque are mainly considered. Simulation results of the system behavior under study confirm the capability of the proposed control.
\end{abstract}

This is an open access article under the CC BY-SA license.

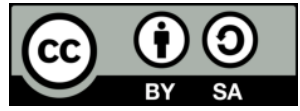

\section{Corresponding Author:}

\section{Sharawy}

Electrical Engineering Department

Faculty of Engineering at Shoubra, Benha University

108 Shobra, Borham, Elsahel, Cairo Governorate, Cairo, Egypt

Email: mohamed.anwer@feng.bu.edu.eg

\section{INTRODUCTION}

Stand-alone wind energy conversion systems (WECSs) employed with doubly fed induction generator (DFIG) are a reliable solution for supplying small power consumers in areas isolated from the grid [1], as the numerous advantages such as reduced power converter rating, operation under variable speed, less losses with improved efficiency, decoupled active and reactive power control, and economically wise [2], [3]. DFIG can supply power to an isolated load at constant voltage and frequency (VF) irrespective of the variation of wind speed and the connected loads. In order to achieve constant VF most of authors have suggested the fieldoriented control (FOC) strategy [1]. The output voltage is regulated indirectly by controlling the amplitude of the excitation current of the rotor (regulating the flux in the machine) while the output frequency is kept constant by imposing rotor currents with slip frequency [1]. If a bi-directional alternating current-alternating current (AC-AC) converter is connected to the rotor circuit, the range of speed can be expanded above synchronous speed and enables power production from both the stator side and rotor side. This converter consists of rotor side converter (RSC) and load side converter (LSC). RSC is used to control the stator VF and LSC is used to regulate the direct current (DC) bus voltage, harmonics compensation and load balancing [4]-[7]. Other advantage of usage of a this converter is that the converter rating is a fraction of the total output power, where this fraction is depending on the allowable operating speed range [8]-[10].

In isolated area applications, the static loads like heating and lighting are mostly used. A large amount of researches have been done on different aspects of the static loads (balanced, unbalanced, linear, 
and non-linear) on DFIG dynamic performances [2], [5]. However, a few amount of them are focused on the dynamic loads such as induction motors (IMs) [6], [11]. References [6] and [11] presented the control strategies for both RSC and LSC to regulate stator output VF at rated values for variable speed operation with dynamic loads. The control strategy is tested by directly connected IM of small size compared to DFIG rating

The IM loads like farm irrigation pumps, ventilation fans used in livestock housing, air compressors, and small pistons are used in the agricultural areas [12]. Hence, the dynamic interactions studies between the IM loads and DFIGs are needed. As known, IMs which are directly connected to the supply draw several times (8-9 times) their rated motor current with low power factor. Also, they consume a high amount of reactive power during start-up period. As a result, a voltage dip is produced which its amount is directly related to the reactive power need of the motor during start-up [13]. This voltage dip causes a reduction of the motor torque the during start-up period and repeated tripping for relays especially in separated power systems [14].

In a specific installation in which the major load is a 3-phase IM and directly online start-up method is used, the generator rating is sized to the apparent power that is consumed by the motor during the start-up period. Hence, in order to meet the IM power requirements, the generator rating must be sized up to 8-9 times the capacity of the motor power [13]. Hence, high cost is required for the electrical system equipment such as transformers, cables, and circuit breakers as they require to be scaled to the value higher than the required value at steady-state condition to sustain the motor start-up requirements [14]. A several methods in [15], [16] have been employed to mitigate the voltage sag caused by the start-up process for IMs in order not to exceed the permissible values for IM loads which is about $21 \%$ [17]. These methods are: a) reduced voltage electromechanically by using auto-transformers, dampers, resistors, and star-delta start), b) capacitor assisted starting, c) reduced voltage by using solid state switches such as soft starters, d) adjustable speed AC drives, e) starting duty rated ]16[, [18]. The usage of those methods to maintain the supply voltage at acceptable levels is considered as expensive solutions.

In this paper, the dynamic performance and control of a stand-alone DFIG feeds a 3-phase IM loaded by speed-squared mechanical torque is presented. The output VF of the DFIG is controlled through the RSC by applying a constant V/f control during start-up period of IM side by side with indirect FOC. The main goal of the proposed control strategy is to overcome the voltage sag across the DFIG terminals caused by direct on-line start of relatively large IM with respect to the size of the DFIG. Before the connection of IM, the controller starts the DFIG at low values of stator output VF. The reference values of stator output VF are chosen so that the ratio V/f maintained constant. After the IM is connected, the DFIG output VF is gradually increased, with V/f ratio maintained constant, until they reach their nominal values.

The results show that by applying this procedure the starting current of IM is reduced and voltage sag problem is mitigated during start-up period and not exceeding the allowed limits. Thus, the advantage of this method is that the problems of the high start-up current and consequentially the voltage sag are solved with a cost-effective control scheme without oversizing for the DFIG ratings or employment of special starters. Simulation results of the system behavior during transient and dynamic phases using MATLAB/Simulink package confirm the capability of the proposed control system.

\section{SYSTEM CONFIGURATION}

The stand-alone WECS configuration of DFIG based with IM load is shown in Figure 1. It consists of wind turbine (WT) drives a DFIG via a gear box (GB). A battery is connected to the DFIG through bidirectional 3-phase pulse width modulation (PWM) RSC to control the DFIG output VF via the rotor currents. The IM is directly connected to the stator of DFIG via a circuit breaker (CB). The motor drives a mechanical load with speed squared torques characteristics such as an irrigation pump. A C-filter is used to reduce stator output voltage harmonics.

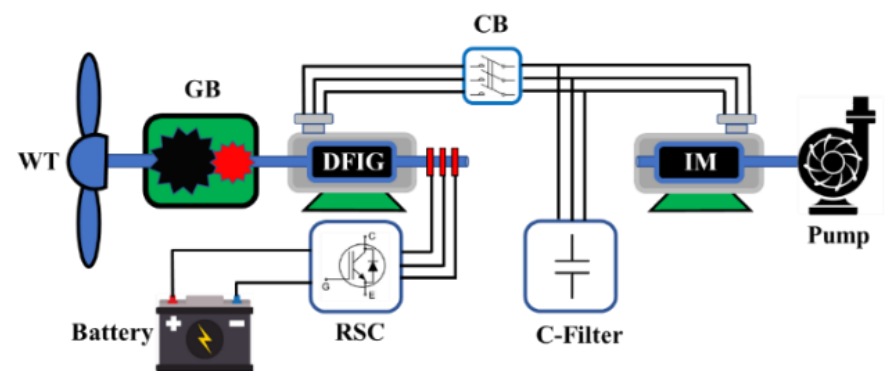

Figure 1. System configuration of DFIG-based stand-alone WECS with IM load 


\section{DYNAMIC PERFORMANCE OF 3-PHASE IM DIRECTLY CONNECTED TO DFIG AT RATED OUTPUT VF}

When a 3-phase IM connected to stand-alone DFIG, the terminal VF must be constant. This can be implemented by controlling the rotor input currents through RSC and battery. Figure 2 shows the indirect FOC algorithm scheme of RSC connected to DFIG based on direct voltage control [4]. The main purpose of the RSC is to maintain the stator output VF of DFIG constant at rated values irrespective of wind speed and loads variations. The advantages of direct voltage control method such as being independent of machine parameters and regulating stator voltage more accurately [19]. Controlling RSC strategy is implemented using two independent control loops, one of them controls the DFIG stator output frequency (frequency control loop) and the other one controls the magnitude of the DFIG stator output voltage (voltage control loop). Rotor current $d$ and $q$-axis components, $i_{d r}$, and $i_{q r}$ are used as the independent control variables to force stator-flux space vector to be aligned with the $d$-axis of the synchronously rotating reference frame [20].

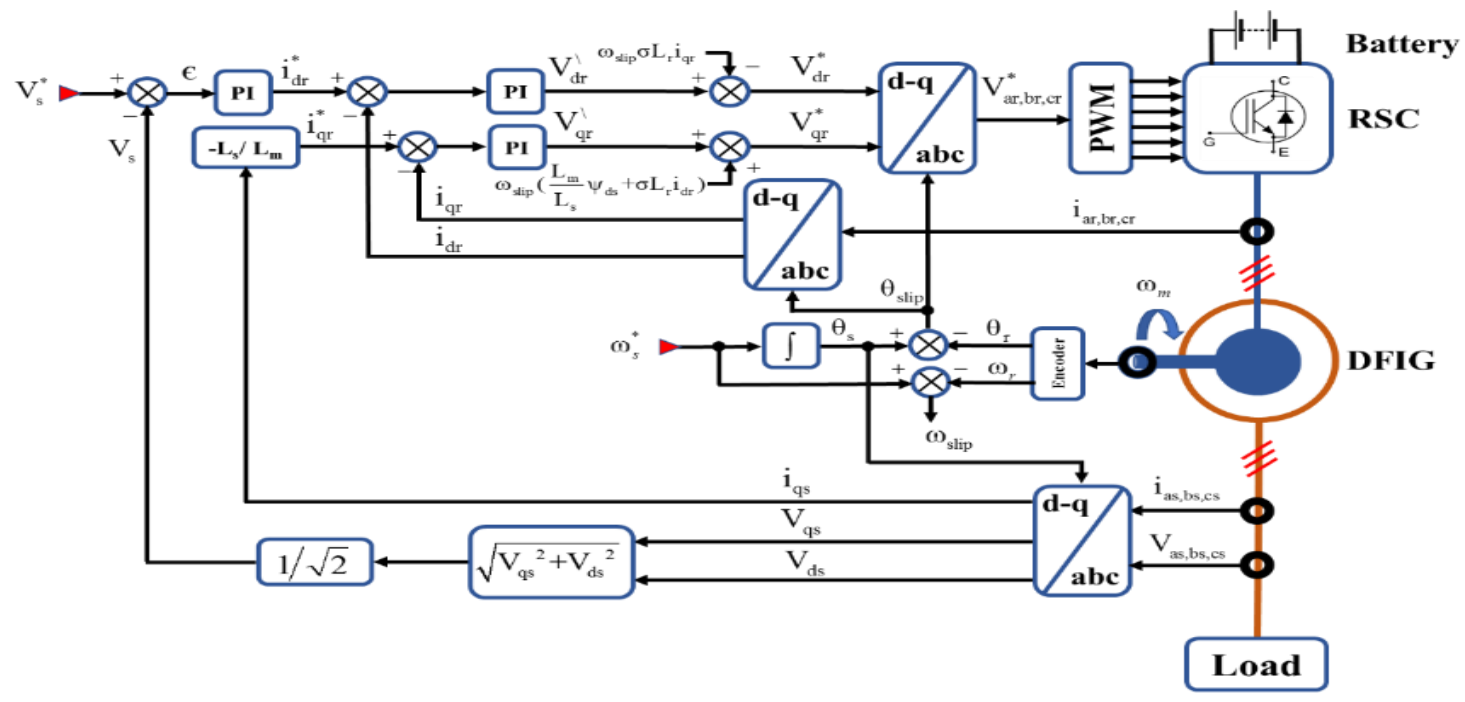

Figure 2. Indirect FOC algorithm scheme of RSC for stand-alone DFIG based on direct voltage control

\subsection{Frequency control loop}

The stator-flux space vector electrical angular-speed should be constant to produce a stator output voltage at desired frequency despite of the connected loads or speed variations. The frequency control is achieved by defining a synchronous reference-frame according to the required output frequency and forcing the stator-flux space vector to be aligned with its $d$-axis. The alignment can be implemented by forcing the reference value of $i_{q r}{ }^{*}$ so that [4], [6], [21]-[23]:

$$
i_{q r}{ }^{*}=-\frac{L_{s}}{L_{m}} i_{q s}
$$

Where $L_{s}$ and $L_{m}$ are the stator and mutual inductance respectively of the DFIG.

\subsection{Voltage control loop}

The voltage control loop is responsible for controlling the magnitude of the DFIG stator output voltage at desired value. This can be achieved directly by controlling the magnitude of the direct axis component of the rotor current $i_{d r}$. The reference direct axis rotor current $i_{d r}{ }^{*}$ is produced by regulating the terminal voltage error $\epsilon$ between reference and estimated actual terminal voltage, where $\epsilon=V_{s}^{*}-V_{s}$, respectively, through PI controller as shown in Figure 2. The actual terminal voltage per phase can be calculated from the measured output voltages after transformed to $d-q$ reference frame is being as [4], [21]-[23]:

$$
\left|V_{s}\right|=\sqrt{V_{q s}^{2}+V_{d s}^{2}}
$$


Then $d$ and $q$-axis reference rotor current components $\left(i_{d r}{ }^{*}\right.$ and $\left.i_{q r}{ }^{*}\right)$ are compared with the measured rotor current components $\left(i_{d r}\right.$ and $i_{q r}$ ) and the current error is passed through the PI controller to give $V_{d r}$, and $V_{q r}{ }^{\prime}$ signals respectively. To ensure good tracking of these currents, compensation terms are added to $V_{d r}$, and $V_{q r}$ in order to obtain the reference voltages $V_{d r}{ }^{*}$, and $V_{q r}{ }^{*}$. Finally, $d$ and $q$-axis reference rotor voltage components $\left(V_{d r}{ }^{*}\right.$, and $\left.V_{q r}{ }^{*}\right)$ are converted into 3-phase reference rotor voltages $V_{a r, b r, c r}{ }^{*}$ using inverse park transformation with slip angle $\left(\theta_{\text {slip }}\right)$ which can be determine is being as [4], [6], [21]-[23]:

$$
\theta_{\text {slip }}=\theta_{s}-\theta_{r}
$$

Where $\theta_{s}$ is the angle calculated by integrating the fixed electrical angular speed $\left(\omega_{s} \mathrm{rad} / \mathrm{sec}\right)$ and $\theta_{r}$ is the electrical rotor angle calculated from the encoder pulses. These reference rotor voltages $\left(V_{a r, b r, c r}{ }^{*}\right)$ are used to estimate the modulating signals which is compared with the fixed frequency PWM for switching the RSC.

\subsection{Simulation results and discussion}

The previous control strategy is applied on $15 \mathrm{~kW}, 380 \mathrm{~V}, 32 \mathrm{~A}, 50 \mathrm{~Hz}$ DFIG to produce rated stator output VF during starting of 3-phase IM. Two $380 \mathrm{~V}, 50 \mathrm{~Hz}, 3$-phase IMs are chosen with smaller rating of $5.4 \mathrm{hp}(4 \mathrm{~kW})$, and larger rating of $10 \mathrm{hp}(7.5 \mathrm{~kW})$. The IMs are loaded with speed-squared mechanical torque. All parameters of the DFIG and IMs are shown as:

a. DFIG parameters [24]:

$15 \mathrm{~kW}, 3$ Phase, 4 pole, $50 \mathrm{~Hz}, \mathrm{R}_{\mathrm{s}}=0.161 \Omega, \mathrm{R}_{\mathrm{r}}=0.178 \Omega, \mathrm{L}_{\mathrm{s}}=\mathrm{L}_{\mathrm{r}}=49.5 \mathrm{mH}, \mathrm{L}_{\mathrm{m}}=46.5 \mathrm{mH}$, Stator: $380 \mathrm{~V}$, 32 A, Rotor: $380 \mathrm{~V}$

b. IMs parameters [25]:

2.1) $5.4 \mathrm{HP}(4 \mathrm{~kW}), 380 \mathrm{~V}, 50 \mathrm{~Hz}, 4$ pole, $1430 \mathrm{rpm}, \mathrm{R}_{\mathrm{s}}=1.405 \Omega, \mathrm{R}_{\mathrm{r}}=1.395 \Omega, \mathrm{L}_{\mathrm{s}}=\mathrm{L}_{\mathrm{r}}=178 \mathrm{mH}$,

$\mathrm{L}_{\mathrm{m}}=172.2 \mathrm{mH}, \mathrm{J}=0.0131 \mathrm{~kg} . \mathrm{m}^{\wedge}, \mathrm{F}=0.002985$ N.m.s.

2.2) $10 \mathrm{HP}(7.5 \mathrm{~kW}), 380 \mathrm{~V}, 50 \mathrm{~Hz}, 4$ pole, $1440 \mathrm{rpm}, \mathrm{R}_{\mathrm{s}}=0.7384 \Omega, \mathrm{R}_{\mathrm{r}}=0.7402 \Omega$, Ls= $\mathrm{L}_{\mathrm{r}}=127.1 \mathrm{mH}$,

$\mathrm{L}_{\mathrm{m}}=124.1 \mathrm{mH}, \mathrm{J}=0.0343 \mathrm{~kg} . \mathrm{m}^{2}, \mathrm{~F}=0.000503$ N.m.s.

The DFIG is operated at super synchronous speed mode of operation with constant speed equal $1550 \mathrm{rpm}$. The two IMs are directly connected and disconnected separately to the stator terminal of DFIG in each case. Results recorded for DFIG are instantaneous stator phase voltages $v_{a s, b s, c s}$, currents $i_{a s, b s, c s}$, rotor direct $i_{d r}$ and quadrature $i_{q r}$ current components, phase rotor currents $i_{a r, b r, c s}$, stator output phase voltage magnitude $V_{s, r m s}$, and stator output phase current magnitude $I_{s, r m s}$. Also, the results recorded for the connected IMs such as motor torque $T_{m}$ and motor speed $N_{m}$.

\subsubsection{Dynamic performance of $5.4 \mathrm{hp}(4 \mathrm{~kW}) 3$-phase IM}

The dynamic performance of $5.4 \mathrm{hp}(4 \mathrm{~kW})$ IM directly connected to DFIG at rated output voltage $220 \mathrm{~V}$ per phase and frequency $F_{s}=50 \mathrm{~Hz}$ with rotor frequency $F_{r}=1.67 \mathrm{~Hz}$ is implemented with simulation time $t=1$ sec. The DFIG firstly started at no loaded from $t=0$ to $t=0.3 \mathrm{sec}$. At $t=0.3 \mathrm{sec}$. the IM is directly connected to DFIG terminals until it reaches to steady state. At $\mathrm{t}=0.7 \mathrm{IM}$ is disconnected. Figure 3 (a) and Figure 3 (b) show the instantaneous and magnitude of stator output voltage, $v_{a s, b s, c s}$ and $V_{s, r m s}$ respectively. As shown the voltage dip and overshot reaches to $20 \%$ and $5 \%$ respectively from its rated value during transient period for connection of IM. Hence the voltage dip does not exceed the permissible limits of $21 \%$ from its rated value. Also, the voltage overshot reaches to $3.2 \%$ during transient period at disconnection of IM. Figure 3 (c) and Figure 3 (d) show the instantaneous and magnitude of stator output currents, $i_{a s, b s, c s}$ and $I_{s, r m s}$ respectively. As shown the starting current is about 5 times the rated current of IM and 1.5 times the rated current of DFIG. Figure 3 (e) shows the corresponding abc rotor currents $i_{a r, b r, c r}$. The IM motor torque $T_{m}$ and speed $N_{m}$ are shown in Figure $3(\mathrm{f})$ and Figure $3(\mathrm{~g})$.

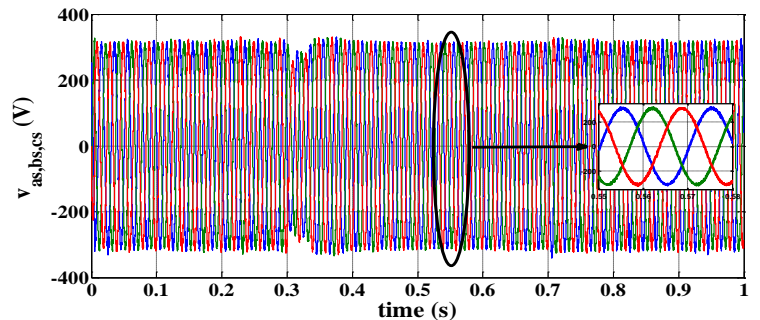

(a)

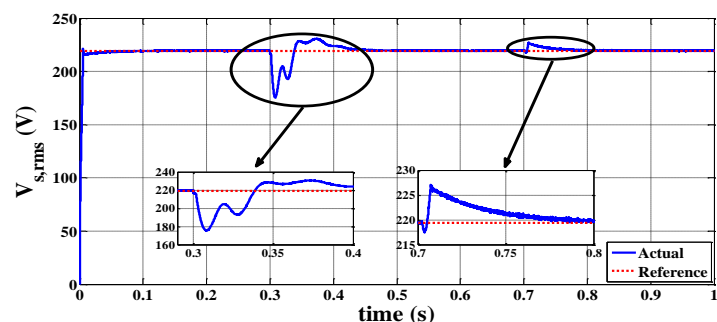

(b)

Figure 3. Dynamic performance of $5.4 \mathrm{hp}(4 \mathrm{~kW})$ IM directly connected to DFIG at rated VF; (a) $v_{a s, b s, c s}$, (b) $V_{s, r m s}$ 


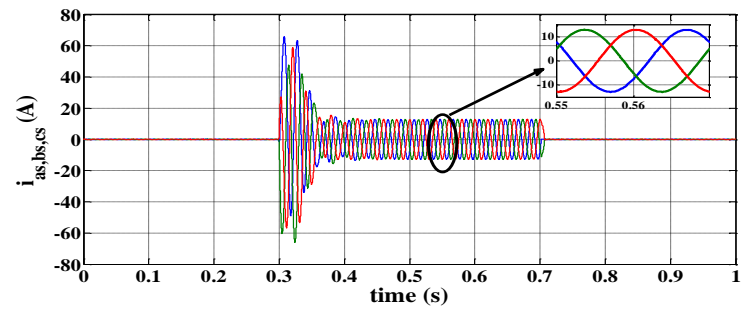

(c)

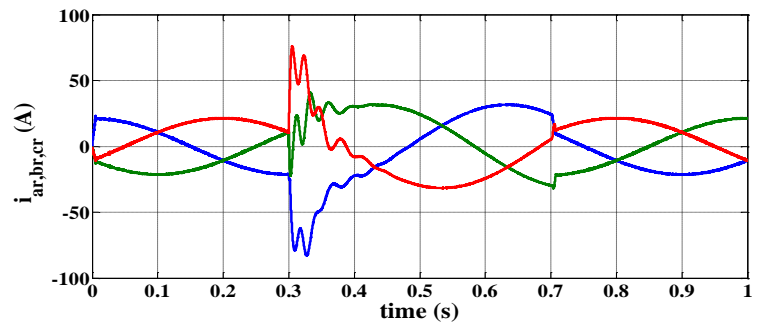

(e)

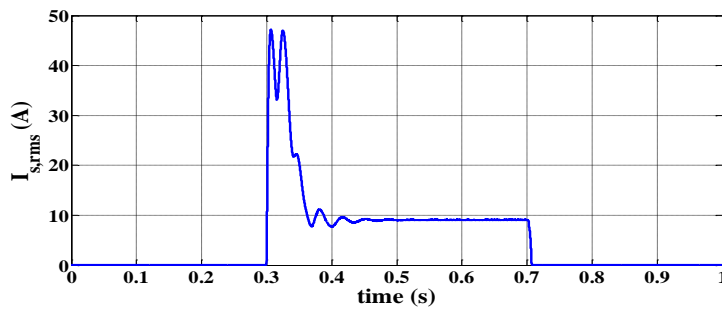

(d)

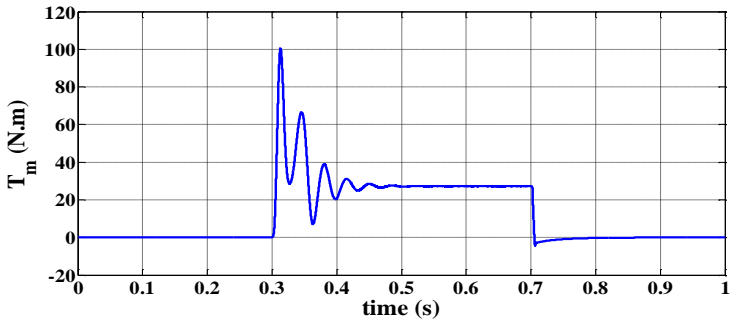

(f)

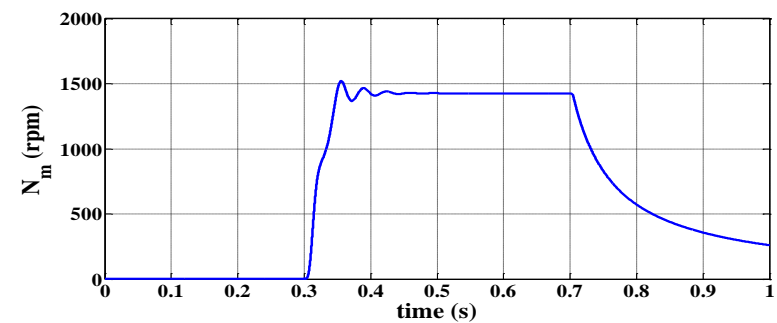

(g)

Figure 3. Dynamic performance of $5.4 \mathrm{hp}(4 \mathrm{~kW})$ IM directly connected to DFIG at rated VF; (c) $i_{a s, b s, c s}$, (d) $I_{s, r m s}$, (e) $i_{a r, b r, c r}$, (f) $T_{m}$, (g) $N_{\mathrm{m}}$ (continue)

\subsubsection{Dynamic performance of $10 \mathrm{hp}(7.5 \mathrm{~kW})$ 3-phase IM}

The dynamic performance of $10 \mathrm{hp}(7.5 \mathrm{~kW})$ IM directly connected to DFIG at rated output voltage $220 \mathrm{~V}$ per phase and frequency $F_{s}=50 \mathrm{~Hz}$ with rotor frequency $F_{r}=1.67 \mathrm{~Hz}$ is implemented with simulation time $\mathrm{t}=0.5 \mathrm{sec}$. The DFIG firstly started at no loaded from $\mathrm{t}=0$ to $\mathrm{t}=0.3 \mathrm{sec}$. At $\mathrm{t}=0.3 \mathrm{sec}$. the IM is directly connected to DFIG terminals. Figure 4 (a) and Figure 4 (b) show the instantaneous and magnitude of stator output voltage, $v_{a s, b s, c s}$ and $V_{s, r m s}$ respectively. As shown the voltage dip exceeds the permissible limits of $21 \%$ at the instant of start-up. So, the CB disconnect IM from the DFIG terminal to protect the IM from this undervoltage which may reach to $32 \%$ from its rated value at this instant. Figure 4 (c) and Figure 4 (d) show the instantaneous and magnitude of stator output currents, $i_{a s, b s, c s}$ and $I_{s, r m s}$ respectively. As shown the starting current is about 6 times the rated current of IM and 2.5 times the rated current of DFIG. Figure 4 (e) shows the corresponding abc rotor currents $i_{a r, b r, c r}$. The IM motor torque $T_{m}$ and speed $N_{m}$ are shown in Figure 4 (f) and Figure 4 (g).

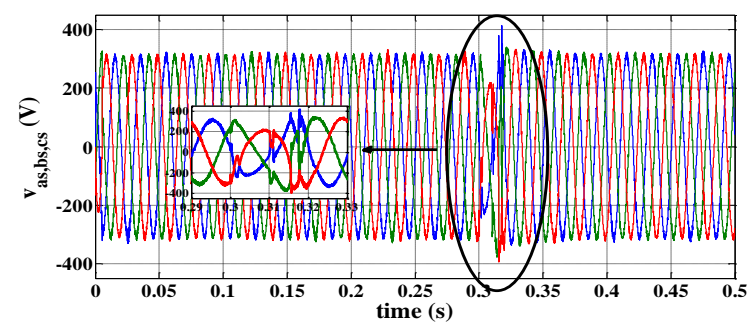

(a)

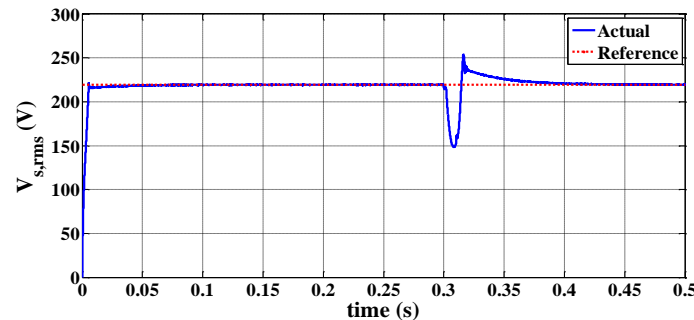

(b)

Figure 4. Dynamic performance of $10 \mathrm{hp}\left(7.5 \mathrm{~kW}\right.$ ) IM directly connected to DFIG at rated VF; (a) $v_{a s, b s, c s}$, (b) $V_{s, r m s}$ 


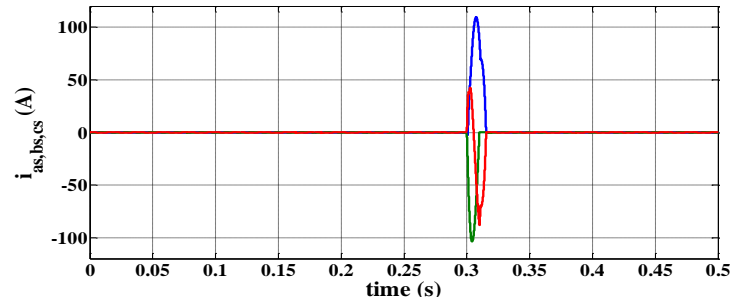

(c)

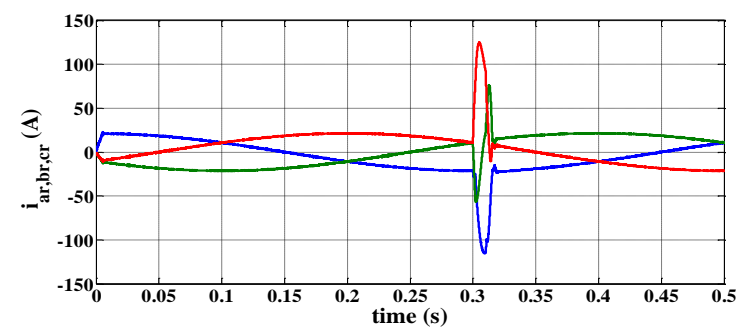

(e)

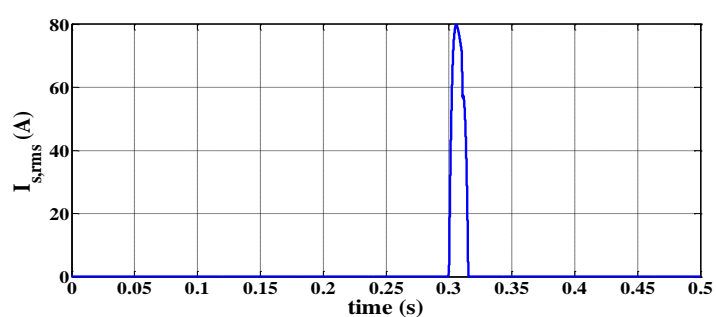

(d)

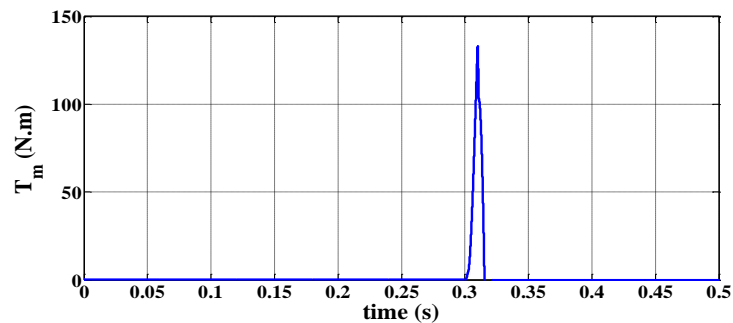

(f)

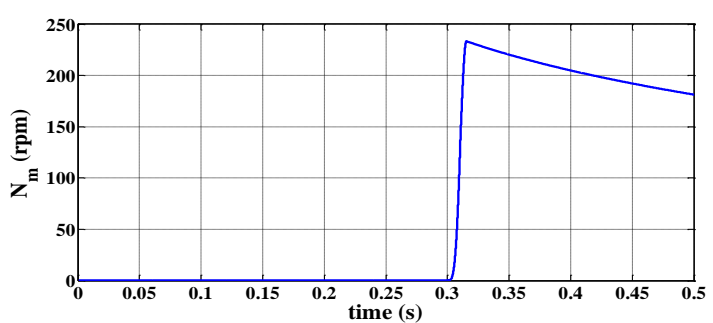

(g)

Figure 4. Dynamic performance of $10 \mathrm{hp}(7.5 \mathrm{~kW})$ IM directly connected to DFIG at rated VF; (c) $i_{a s, b s, c s}$, (d) $I_{s, r m s,}$ (e) $i_{a r, b r, c r}$, (f) $T_{m}$, (g) $N_{\mathrm{m}}$ (continue)

\section{PROPOSED CONTROL STRATEGY FOR DFIG FEEDING 3-PHASE IM}

As explained previously, the smaller rating IM succeed to start-up, but the larger rating IM failed to start-up when the two motors are directly connected to DFIG terminals at rated stator VF. By controlling the RSC, DFIG can be operated at any desired stator output VF as long as doesn't exceed the rating of the generator. Also, the generator can be operated at rated output VF or less than those rated values as long as keeping the ratio of V/f for the machine constant consequentially the flux of the machine maintain constant. Hence, the DFIG output VF can be set at low values at the start-up of 3-phase larger rating IM to overcome the starting problems.

\subsection{Determination methodology for references values of stator output VF of DFIG}

Figure 5 shows the proposed control methodology of RSC for choosing the references values of stator output VF for DFIG by changing the switch position between (a) and (b). For smaller rating of IM, the switch position is set at position (a) the controller set the generator frequency at rated value and hence rated output voltage. For larger rating of IM, the switch position is set at position (b) the controller operates DFIG at variable stator output VF with constant V/f ratio according to the ramp input function. The controller starts the DFIG at low values of stator output VF with constant V/f ratio before the connection of IM. When the IM is connected, the DFIG output VF is gradually increased, with V/f ratio maintained constant, until it reaches its nominal values. The saturation block limits the output frequency from controller from lower preset value to the rated value of the DFIG. By this procedure the starting current of IM can be reduced during transient period.

\subsection{Simulation results and discussion}

The dynamic performance of $10 \mathrm{hp}(7.5 \mathrm{~kW})$ IM directly connected to DFIG at variable stator output VF with V/f constant is implemented with simulation time $\mathrm{t}=1.5 \mathrm{sec}$. The DFIG firstly started at no load with low stator output voltage equal to $44 \mathrm{~V}$ per phase and output frequency equal to $10 \mathrm{~Hz}$ from t=0 to $\mathrm{t}=0.4 \mathrm{sec}$. At $\mathrm{t}=0.4 \mathrm{sec}$. the IM is directly connected to DFIG terminals. The IM is disconnected at $\mathrm{t}=1.2 \mathrm{sec}$. 
Figure 6 (a), Figure 6 (b), and Figure 6 (c) show the instantaneous, magnitude, and frequency of stator output voltage, $v_{a s, b s, c s}, V_{s, r m s}$ and $F_{s}$ respectively. As shown the voltage dip is reduced and reaches only to $18 \%$ from its rated value at the instant of connection of IM which is below the permissible limits. Also, the voltage overshot reaches to $3.2 \%$ during transient period at disconnection of IM. Figure 6 (d) and Figure $6 €$ show the instantaneous and magnitude of stator output currents, $i_{a s, b s, c s}$ and $I_{s, r m s}$ respectively. As shown the starting current is reduced to 1.9 times the rated current of IM and 0.8 times the rated current of DFIG. Figure 6 (f) and Figure $6(\mathrm{~g})$ show the corresponding abc rotor currents $i_{a r, b r, c r}$ and its frequency $F_{r}$. The IM motor torque $T_{m}$ and speed $N_{m}$ are shown in Figure 6 (h) and Figure 6 (i). As shown, by this method the larger rating of 3-phase IM is succeed to start-up without exceeding the permissible limits of voltage dip.

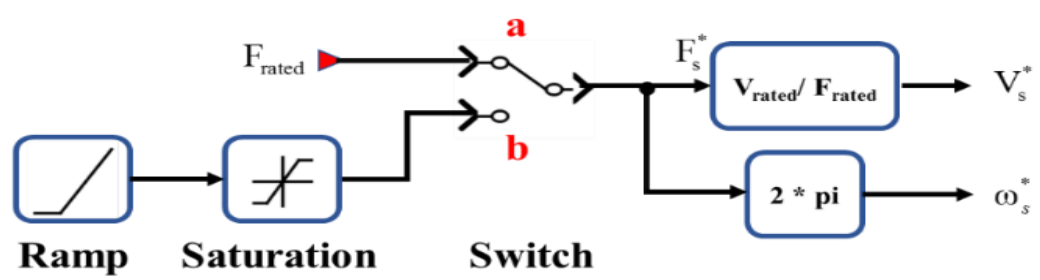

Figure 1. Proposed control methodology of RSC for choosing the references values of stator output VF references

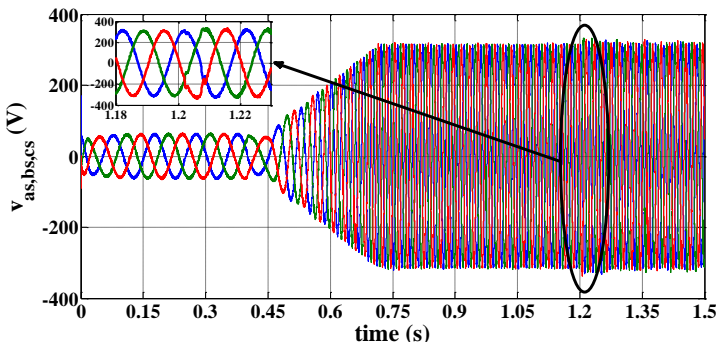

(a)

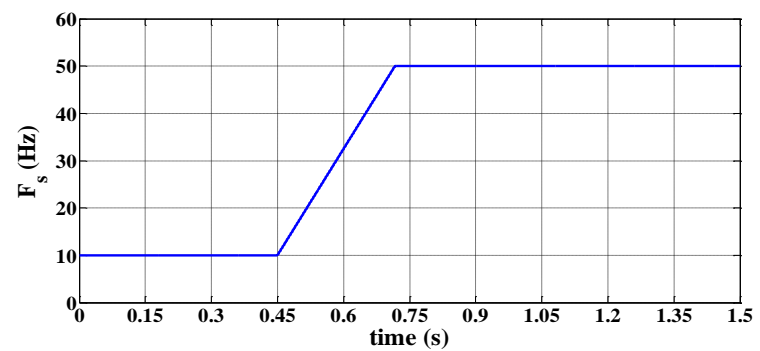

(c)

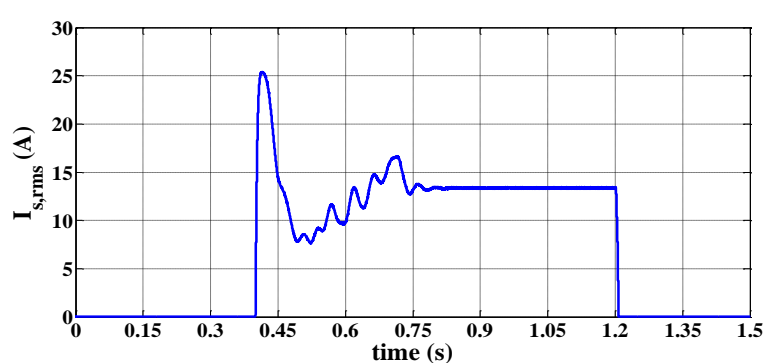

(e)

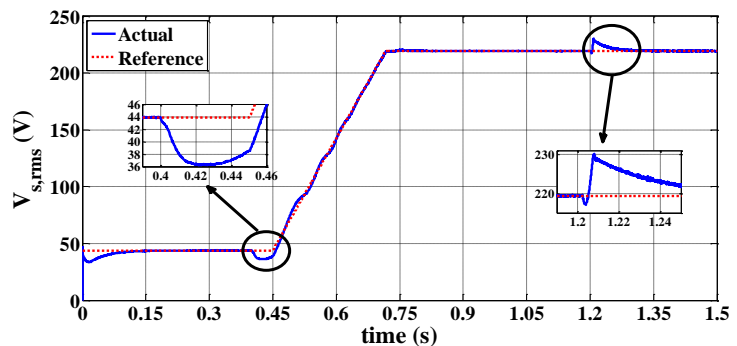

(b)

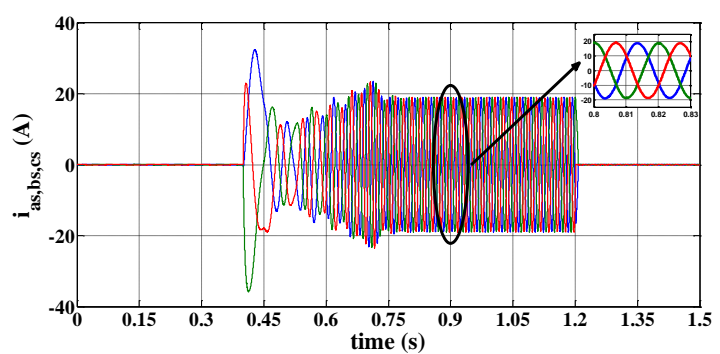

(d)

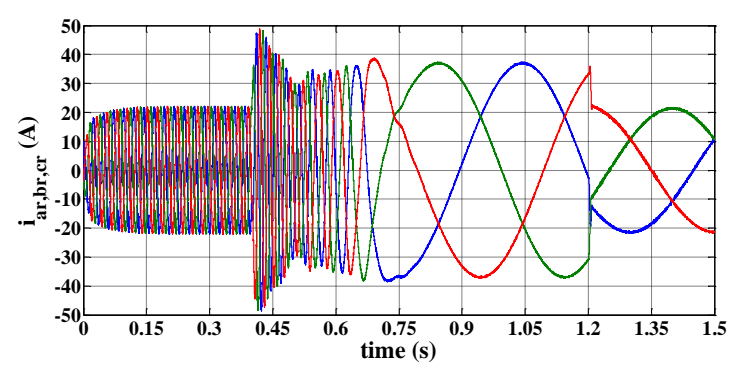

(f)

Figure 2. Dynamic performance of $10 \mathrm{hp}(7.5 \mathrm{~kW})$ IM directly connected to DFIG at variable stator output VF with V/f constant; (a) $v_{a s, \mathrm{bs}, \mathrm{cs}}$, (b) $V_{s, r m s}$, (c) $i_{a s, b s, c s}$, (d) $I_{s, r m s}$, (e) $F_{s}$, (f) $i_{a r, b r, c r}$ 


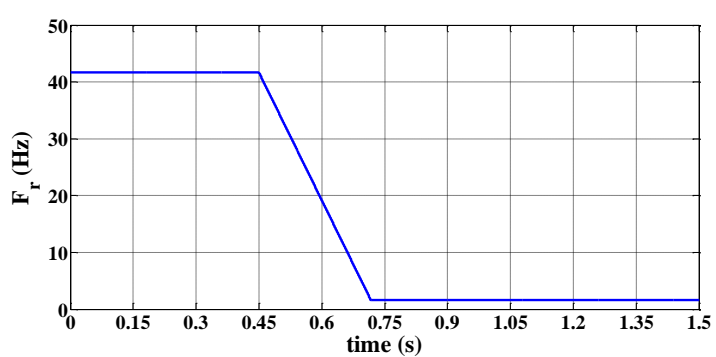

(g)

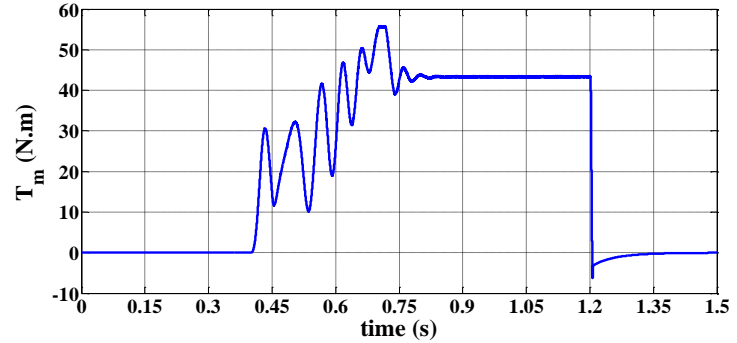

(h)

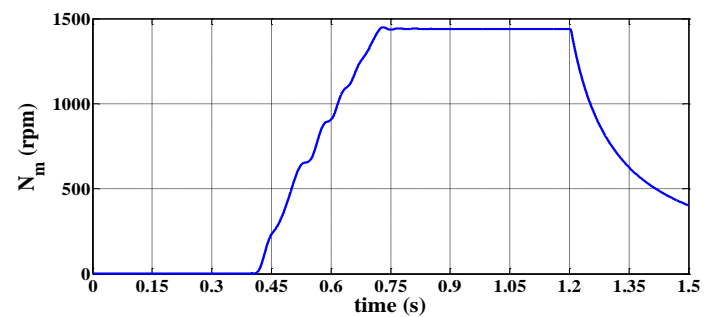

(i)

Figure 3. Dynamic performance of $10 \mathrm{hp}(7.5 \mathrm{~kW})$ IM directly connected to DFIG at variable stator output VF with V/f constant; (g) $F_{r}$, (h) $T_{m}$, (i) $N_{m}$ (continue)

\section{CONCLUSION}

Direct online starting method of three phase IMs fed by DFIM in stand-alone WECS causes large starting current and consequentially large voltage dip which depending on the connected IMs rating. Two IMs with different ratings are directly connected to DFIG at rated VF. The voltage dip caused by smaller rating IM doesn't exceed the permissible limits during starting period while the larger one exceeds the permissible limits during starting period. A variable stator output VF with V/f constant control algorism is applied to RSC to control the stator output VF of DFIG during start-up period of IMs. This procedure contributed to reduce the IM starting current and mitigate the voltage sag within the permissible limits without oversizing of the DFIG rating or employment of special starters.

\section{REFERENCES}

[1] F. Abdoune, D. Aouzellag, and K. Ghedamsi, "Terminal voltage build-up and control of a DFIG based stand-alone wind energy conversion system," Renewable Energy, vol. 97, pp. 468-480, November 2016, doi: 10.1016/j.renene.2016.06.005.

[2] R. D. Shukla and R. K. Tripathi, "Isolated Wind Power Supply System using Double-fed Induction Generator for remote areas," Energy Conversion and Management, vol. 96, pp. 473-489, May 2015, doi: 10.1016/j.enconman.2015.02.084.

[3] I. Yasmine, E B. Chakib, and B. Badre, "Improved Performance of DFIG-generators for Wind Turbines Variablespeed," International Journal of Power Electronics and Drive System (IJPEDS), vol. 9, no. 4, pp. 1875-1890, December 2018, doi: 10.11591/ijpeds.v9.i4.pp1875-1890.

[4] S. Soued, et al., "Experimental behaviour analysis for optimally controlled standalone DFIG system," in IET Electric Power Applications, vol. 13, no. 10, pp. 1462-1473, July 2019, doi: 10.1049/iet-epa.2018.5648.

[5] R. D. Shukla and R. K. Tripathi, "A novel voltage and frequency controller for standalone DFIG based Wind Energy Conversion System," Renewable and Sustainable Energy Reviews, vol. 37, pp. 69-89, September 2014, doi: 10.1016/j.rser.2014.04.069.

[6] N. K. S. Naidu and B. Singh, "Experimental Implementation of Doubly Fed Induction Generator-Based Standalone Wind Energy Conversion System," in IEEE Transactions on Industry Applications, vol. 52, no. 4, pp. 3332-3339, July-Aug. 2016, doi: 10.1109/TIA.2016.2542783.

[7] R. Arindya, "A Variable Speed Wind Generation System Based on Doubly Fed Induction Generator," Bulletin of Electrical Engineering and Informatics, vol. 2, no. 4, pp. 272-277, December 2013, doi: 10.11591/eei.v2i4.193.

[8] R. Pena, J. C. Clare, and G. M. Asher, "A doubly fed induction generator using back-to-back PWM converters supplying an isolated load from a variable speed wind turbine," in IEE Proceedings-Electric Power Applications, vol. 143, no. 5, pp. 380-387, May 1996, doi: 10.1049/ip-epa:19960288.

[9] A. A. J. Jeman, N. M. S. Hannoon, N. Hidayat, M. M. H. Adam, I. Musirin, and V. Vijayakumar, "Stability check of doubly fed induction generator (DFIG) micro grid power system," Bulletin of Electrical Engineering and Informatics, vol. 8, no. 2, pp.367-374, June 2019, doi: 10.11591/eei.v8i2.1430. 
[10] A. Boulahia, M. Adel, H. and Benalla, "Predictive Power Control of Grid and Rotor Side Converters in Doubly Fed Induction Generators Based Wind Turbine," Bulletin of Electrical Engineering and Informatics, vol. 2, no. 4, pp. 258 264, December 2013, doi: 10.11591/eei.v2i4.191.

[11] B. Singh and S. Sharma, "Doubly fed induction generator-based off-grid wind energy conversion systems feeding dynamic loads," IET Power Electronics, vol. 6, no. 9, pp. 1917-1926, November 2013, doi: 10.1049/ietpel.2013.0010

[12] P. Aree, "Starting performance of induction motor under isolated self-excited induction geneator," 2015 12th International Conference on Electrical Engineering/Electronics, Computer, Telecommunications and Information Technology (ECTI-CON), 2015, pp. 1-5, doi: 10.1109/ECTICon.2015.7207046.

[13] F. B. Silva, W. E. Vanço, F. A. Gonçalves, C. A. Bissochi, D. P. Carvalho, and G. C. Guimarães, "A proposal for the study of voltage sag in isolated synchronous generators caused by induction motor start-up," Electric Power Systems Research, vol. 140, pp. 776-785, November 2016, doi: 10.1016/j.epsr.2016.05.008.

[14] M. Falahi, K. L. Butler-Purry, and M. Ehsani, "Induction Motor Starting in Islanded Microgrids," in IEEE Transactions on Smart Grid, vol. 4, no. 3, pp. 1323-1331, Sept. 2013, doi: 10.1109/TSG.2013.2271261.

[15] S. Leng, A. R. N. M. R. Ul Haque, N. Perera, A. Knight and J. Salmon, "Soft Start and Voltage Control of Induction Motors Using Floating Capacitor H-Bridge Converters," in IEEE Transactions on Industry Applications, vol. 52, no. 4, pp. 3115-3123, July-Aug. 2016, doi: 10.1109/TIA.2016.2539253.

[16] A. H. VanderMeulen, T. J. Natali, T. J. Dionise, G. Paradiso, and K. Ameele, "Exploring New and Conventional Starting Methods of Large Medium-Voltage Induction Motors on Limited kVA Sources," in IEEE Transactions on Industry Applications, vol. 55, no. 5, pp. 4474-4482, Sept.-Oct. 2019, doi: 10.1109/TIA.2019.2922339.

[17] J. Nevelsteen and H. Aragon, "Starting of large motors-methods and economics," in IEEE Transactions on Industry Applications, vol. 25, no. 6, pp. 1012-1018, Nov.-Dec. 1989, doi: 10.1109/28.44236.

[18] S. Leng, A. R. N. M. R. Ul Haque, N. Perera, A. Knight, and J. Salmon, "Soft Start and Voltage Control of Induction Motors Using Floating Capacitor H-Bridge Converters," in IEEE Transactions on Industry Applications, vol. 52, no. 4, pp. 3115-3123, July-Aug. 2016, doi: 10.1109/TIA.2016.2539253.

[19] M. Noroozi and S. Farhangi, "Voltage and frequency stability for control of stand-alone DFIG-based wind turbine using direct voltage control method," 2014 14th International Conference on Environment and Electrical Engineering, 2014, pp. 85-90, doi: 10.1109/EEEIC.2014.6835842.

[20] D. Forchetti, G. Garcia, and M. I. Valla, "Vector control strategy for a doubly-fed stand-alone induction generator," IEEE 2002 28th Annual Conference of the Industrial Electronics Society. IECON 02, 2002, pp. 991-995 vol. 2, doi: 10.1109/IECON.2002.1185407.

[21] M. S. Chabani, M. T. Benchouia, A. Golea, and R. Boumaaraf, "Implementation of direct stator voltage control of stand-alone DFIG-based wind energy conversion system," 2017 th International Conference on Electrical Engineering - Boumerdes (ICEE-B), 2017, pp. 1-6, doi: 10.1109/ICEE-B.2017.8192060.

[22] K. Abdoune, F. Abdoune, and D. Aouzellag, "Vector control of doubly-fed induction machine for stand-alone variable speed energy system," 2018 International Conference on Electrical Sciences and Technologies in Maghreb (CISTEM), 2018, pp. 1-6, doi: 10.1109/CISTEM.2018.8613559.

[23] B. B. M. El Amine, A. Ahmed, M. B. Houari, and D. Mouloud, "Modeling, simulation and control of a doubly-fed induction generator for wind energy conversion systems," International Journal of Power Electronics and Drive System (IJPEDS), vol. 11, no. 3, pp. 1197-1210, September 2020, doi: 10.11591/ijpeds.v11.i3.pp1197-1210.

[24] G. Abad, J. López, M. A. Rodrı'guez, L. Marroyo, and G. Iwanski, "Doubly Fed Induction Machine Modeling and Control for Wind Energy Generation," IEEE Press 445 Hoes Lane Piscataway, NJ 08854, November 2011.

[25] MathWorks, " Asynchronous Mac..hine", United States, 1994-2021, [Online]. Available: https://www.mathworks.com/help/physmod/sps/powersys/ref/asynchronousmachine.html

\section{BIOGRAPHIES OF AUTHORS}
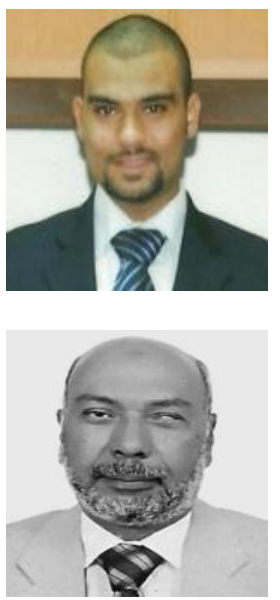

M. Sharawy graduated from Benha University in 2010 and received the M.Sc. degree from Cairo University, Cairo, Egypt, in 2016. He is currently a teaching assistant at the department of Electrical Engineering in Faculty of Engineering at Shoubra, Cairo, Egypt. His fields of interest include Electrical Machines, Power Electronics, Control, and Renewable Energy.

Adel A. Shaltout is a professor at the Electric Power Dept., Cairo University. He obtained his B.Sc. and M.Sc. from Cairo University in 1970 and 1973. He obtained a second M.Sc. from Mc Master University and Ph.D. from University of Saskatchewan, Canada. His field of interest includes electrical machines, power systems and renewable energy sources where he has published more than 190 papers. He is a partner in the Electrical Engineering Consulting Group since 1985 where he has consulted for several industrial firms. 


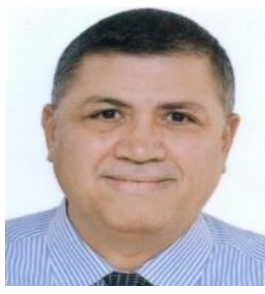

Naser Abdel-Rahim, Ph.D., currently holds the position of Professor in the Department of Electrical Engineering of Future University in Egypt. From 2013 to 2017 he had been a Professor with the Faculty of Engineering at Shoubra, Benha University, Egypt. He received both the M. Eng. and Ph.D. degrees from the Memorial University of Newfoundland in Canada, in 1989 and 1995, respectively. As an Assistant Professor at the United Arab Emirates University (UAEU) from 2000 till 2005, he obtained several research projects funding from the UAEU as well as from Asea Brown Boveri (ABB). Abdel-Rahim has numerous publications in international journals and refereed conferences, where he also served as a reviewer.

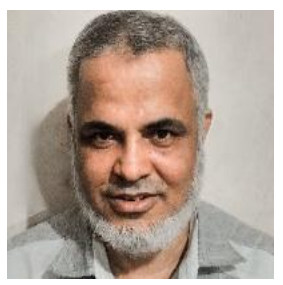

Mahmoud A. AL-Ahmar received the B.Sc., M.Sc. and Ph.D. degrees from Faculty of Engineering (Shoubra), Benha University, Cairo/Egypt in 1982, 1987 and 1993, respectively. From 1982 to 1987, he was a demonstrator and Research Assistant with Benha University. In 1993 he became an Assistant professor and in 1999 he became an Associate professor with Benha University. Since 2019 he has been a professor of Electrical Machines at the Faculty of Engineering (Shoubra) of Benha University.

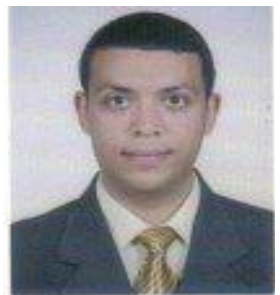

O. E. M. Youssef received the B.Sc. and M.Sc degrees in electrical power and machines from Faculty of Engineering at Shoubra, Benha Branch, Zagazig University, Cairo, Egypt in 1999 and 2004 respectively. He received the Ph.D. degree in Electrical Machines and Electrical Drive Systems from Faculty of Engineering at Shoubra, Benha University, Cairo, Egypt in 2010. He is a Lecturer at the Department of Electrical Engineering, Faculty of Engineering at Shoubra, Benha University. 